\title{
Pengembangan Subject Specific Pedagogy Berbasis Problem Based Learning untuk Penguatan Sikap Peduli Lingkungan pada Siswa SMP
}

\section{Development of Subject Specific Pedagogy on Problem Based Learning to Reinforce Student's Environmental Attitude}

\author{
Rizka Eka Arizka Panca Candraa ${ }^{1, *}$, Puguh Karyanto ${ }^{1}$, Baskoro Adi Prayitno ${ }^{1}$ \\ ${ }^{1}$ Pendidikan Biologi FKIP UNS, Jalan Ir.Sutami 36A Kentingan, Surakarta, Indonesia \\ *Corresponding authors: apcrizka@ yahoo.com \\ Manuscript received: ......... Revision accepted:
}

\begin{abstract}
The aims of this research is to know the characteristics, feasibility, and efectiveness of develop Subject Spesific Pedagogy (SSP) based on Problem Based Learning (PBL) to reinforce student's environmental attitude in Grade VII SMP Negeri 2 Karanganyar academic year 2015/2016. This research is a Research and Development or R\&D which refers to the development of Thiagarajan design (4D). This research model consist of define, design and develop. The stage carried out are limited to ad this stage of development because the purpose of this research only develop product SSP based on PBL. The product's characteristic is integration of PBL syntax and environmental subject. The validation results from expert judgments showed that $87,35 \%$ in module (valid), $85,71 \%$ in RPP (valid), $84,29 \%$ in LKS (valid) and 87,22\% in problem set (valid). The development testing result from students and teacher showed that $86,07 \%$ (valid). NEP data showed that the mean value had been improved from 47,79 up to 61,58 . Paired Sample t-test showed that $s i g=0,000<\alpha(\operatorname{sig}<0,0)$ it's mean there was differences student's environmental attitude between pre and post treatment. The conclusion of this research showed that SSP based on PBL is valid and proper for Grade VII SMP Negeri 2 Karanganyar. SSP based on PBL is effective to improve environmental attitude.
\end{abstract}

Keywords: Subjek Spesifik Pedagogi, Problem Based Learning, Environmental attitude

\section{PENDAHULUAN}

Sikap peduli lingkungan merupakan sikap dan tindakan yang dimiliki seorang individu dalam masyarakat untuk selalu berupaya mencegah kerusakan lingkungan dan memperbaiki kerusakan maupun pencemaran yang terjadi (Narwanti, 2011). Menurut Syah (2009) sikap merupakan respon ditunjukkan oleh seseorang dengan cara yang tetap terhadap objek benda, ide, lingkungan baik secara positif dan negatif. Sikap peduli lingkungan menunjukkan perilaku positif dalam menjaga, melindungi serta melestarikan lingkungan. Sikap dan perilaku manusia akan menentukan baik buruknya kondisi suatu lingkungan, tergantung dari respon kesiapan berperilaku yang ditunjukkan oleh setap individu.

Soemarwoto (2001) menyatakan bahwa hubungan manusia dengan lingkungan hidup sifatnya sirkuler, yaitu aktivitas manusia terhadap lingkungan dapat membawa dampak positif maupun negatif terhadap lingkungan hidup. Dampak aktivitas negatif terhadap lingkungan merupakan umpan balik bagi perilaku yang muncul. Respon terhadap dampak negatif menyebabkan individu berefleksi untuk memperbaiki perilaku. Perilaku yang dilandasi oleh sikap memunculkan Theory of Planned Behaviour yaitu perilaku ramah lingkungan muncul karena dorongan kesiapan untuk berperilaku/ Behavioral Intention (Ajzen, 2001). Kesiapan tersebut dipengaruhi oleh sikap/ behavioral attitude yaitu sikap peduli lingkungan.

Peran individu melalui sikap peduli lingkungan menjadi kunci dalam menangani berbagai permasalahan lingkungan akibat aktifitas manusia. Farhati (1995) menyatakan bahwa sikap dan perilaku seseorang dalam mengambil keputusan terhadap lingkungan merupakan kunci utama dalam usaha meningkatkan kualitas lingkungan. Sikap peduli lingkungan dapat dipraktikan melalui tindakan peduli lingkungan dengan melakukan pelestarian dan pengelolaan sumber daya sesuai kebutuhan.

Sikap peduli lingkungan menjadi penting untuk dibiasakan karena sikap peduli lingkungan mempengaruhi perilaku ramah lingkungan. Kollmuss dan Agyeman (2002) mendeskripsikan bahwa perilaku peduli lingkungan adalah perilaku sadar berupaya meminimalisir dampak negatif yang disebabkan oleh aktifitas seseorang. Masalah lingkungan dapat diatasi apabila seorang mempunyai kesadaran dan rasa tanggung jawab atas perilaku yang dilakukannya terhadap lingkungan.

Kurangnya perilaku sadar lingkungan menyebabkan berbagai permasalahan lingkungan, yaitu apabila manusia tidak bisa mengendalikan aktivitasnya dalam mengelola lingkungan dengan benar maka akan berdampak pada kerusakan lingkungan. Sebagai contoh fenomena lingkungan sekarang ini menjadi pemandangan yang sangat memprihatinkan. Kerusakan hutan tercatat 2,8 juta hektar pertahun hutan di Indonesia hilang sejak tahun 2000-2005 dikarenakan penebangan liar (BNPB, 2011). Keadaan lingkungan semakin memburuk dengan adanya degradasi hutan, pencemaran air akibat limbah industri dan pencemaran udara yang semakin meningkat (Kementrian 
Lingkungan Hidup Republik Indonesia, 2013). Aktivitas tersebut jika tidak segera diatasi dapat merusak komponen dan keseimbangan alam, sehingga akan menjadi ancaman bagi keberlangsungan makhluk hidup.

Upaya untuk mengatasi permasalah lingkungan dilakukan dengan pembiasaan sikap peduli lingkungan. Salah satu strategi untuk membiasakan sikap peduli lingkungan adalah melalui pendidikan. Sumarmi (2008) menyebutkan bahwa penanaman pondasi lingkungan sejak dini menjadi solusi utama, agar generasi muda memiliki pemahaman tentang lingkungan hidup dengan baik dan benar. Upaya penanaman sikap peduli lingkungan dilakukan di jenjang pendidikan yaitu sekolah, berdasarkan Raka, dkk,. (2011) pendidikan karakter di sekolah hendaknya memasukan kepedulian terhadap lingkungan sebagai bagian tema pendidikan untuk menguatkan kesadaran dan tanggung jawab sebagai warga masyarakat. Melalui pendidikan lingkungan hidup, setiap individu tertanam kesadaran menjaga lingkungan, sehingga dapat terbentuk karakter ramah lingkungan. Kesadaan yang dimiliki generasi muda melalui pendidikan dapat mengatasi permasalahan lingkungan, sesuai dengan pernyataan Rahmawati dan Suwanda (2015) bahwa pendidikan merupakan salah satu upaya dalam menekan berkembangnya permasalahan lingkungan.

Rumusan agenda 21, bab 36 bagian IV pada Konferensi Tingkat Tinggi Bumi menyebutkan petingnya pendidikan dalam mencapai tujuan bersama untuk mewujudkan pembangunan berkelanjutan melalui pembangunan karakter ramah lingkungan secara kultural. Berkaitan dengan hal tersebut maka pembangunan berkelanjutan dimplementasikan kedalam pendidikan lingkungan. Rumusan tersebut dikenal dengan istilah Education for Sustainable Development/EfSD, yaitu paradigma baru dibidang pendidikan yang memberikan kesadaran dan kemampuan kepada semua orang terutama generasi muda dalam berkonstribusi dalam pembangunan berkelanjutan (Priyanto, dkk., 2013). Galus (2010) menyebutkan bahwa pembentukan environmental ethics and attitude yang terimplementasi dalam perilaku individual terhadap lingkungan dan gaya hidup yang diikuti sikap ramah lingkungan.

Sikap peduli lingkungan dapat di berdayakan dengan desain pembelajaran spesifik yang memberikan pengalaman belajar sehingga tercipta kebiasaan atau perilaku ramah lingkungan. Pembelajaran spesifik mengenai lingkungan akan memberikan pengetahuan kepada siswa sebagai pengalaman yang mengahasilkan kebiasaan perilaku (Irham \&Wiyani, 2013). Menurut Prasetyo (2011) SSP merupakan pengemasan bidang studi menjadi perangkat pembelajaran komprehensif mencakup standar kompetensi, materi, strategi, metode, media, serta evaluasi. Pembelajaran spesifik diartikan sebagai perangkat pembelajaran yang direncanakan pada pengembangan materi spesifik bidang studi dengan tujuan spesifik. Komponen yang dikembangkan dalam SSP meliputi silabus, RPP, modul, LKS dan alat evaluasi. Terkait dengan pembelajaran spesifik yang memuat materi lingkungan hidup pada mata pelajaran menjadi sarana pembiasaan sehingga memunculkan perilaku ramah lingkungan.

Merujuk pada Theory of Planned Behavior (Ajzen, 2001), perilaku ramah lingkungan dipengaruhi oleh sikap peduli lingkuingan. Sikap peduli lingkungan dapat diukur menggunakan sebuah instrumen skala yang dapat mengukur nilai kesiapan berperilaku ramah lingkungan yaitu instrumen skala NEP dari Dunlap. Skala NEP tersebut sudah diterapkan diberbagai negara karena terbukti sebagai alat ukur yang konsisten setelah diuji cobakan pada beberapa penelitian. NEP hasil revisi memaksimalkan content validity, sebagai satu ukuran (Dunlap et al., 2000). Skala NEP yang telah direvisi mengidentifikasi lima dimensi ekologi yang dijabarkan dalam 15 pernyatan mengenai perilaku pro maupun anti lingkungan. Dimensi ekologi tersebut antara lain balance-of nature, limits to growth, anti anthropocenytism, anti-exemptionalism dan eco-crisis. Penjabaran 15 pernyataan tersebut diukur menggunakan skala likert, semakin tinggi skor skala NEP, maka semakin tinggi pula tingkat kepedulian terhadap lingkungan.

SMP N 2 Karanganyar merupakan sekolah yang berbasis adiwiyata yaitu sekolah yang menanamkan pendidikan lingkungan hidup ke dalam materi pelajaran menuju pembangunan berkelanjutan. Pemberian materi lingkungan hidup pada jenjang SMP jelas bertujuan membentuk perilaku keseharian yang ramah lingkungan, sehingga berpengaruh pada nilai afektif dan kognitif hasil belajar siswa. Data tentang sikap peduli lingkungan tetap diperlukan untuk mengetahui seberapa besar kepedulian siswa terhadap lingkungan, sehingga dilakukan penyebarkan angket New Ecological Paradigm (NEP). Hasil angket skala NEP menunjukkan rata-rata nilai 47,79 dari 63 siswa berada pada kategori cukup ramah lingkungan. Hasil presentase yang diperoleh adalah $98 \%$ siswa berada dalam katagori belum memiliki kesiapan berperilaku, sehingga hal ini membuktikan bahwa sikap peduli lingkungan siswa tergolong rendah.

Perhitungan angket NEP setiap dimensi menunjukkan urutan nilai paling rendah dimulai pada dimensi antiexemptionalism dengan rerata hasil angket 8,2 termasuk dalam kategori rendah peduli lingkungan, balance of nature 9,2 termasuk dalam kategori cukup peduli lingkungan, anti anthropocentrism 9,8 termasuk dalam kategori cukup peduli lingkungan, eco-crisis 9,9 termasuk dalam kategori cukup peduli lingkungan dan limits to growth 10,5 termasuk dalam kategori cukup peduli lingkungan. Hasil angket pada lima komponen ini digunakan untuk menyusun perangkat SSP.

Berdasarkan data tersebut maka perlu upaya untuk meningkatkan siswa agar selalu berperilaku ramah lingkungan melalui sikap peduli lngkungan dengan mengembangkan SSP pada mata pelajaran. Upaya tersebut dilakukan dengan pememilihan model pembelajaran yang sesuai, sehingga tercapai tujuan pembelajaran dan mampu memberikan kesempatan siswa lebih aktif menanggapi masalah, menggali informasi, mengemukakan ide, dan mencari solusi terhadap suatu masalah (Sujarwo, 2011). Sanjaya (2009) menyatakan model pembelajaran yang 
dapat digunakan untuk membelajarkan pendidikan lingkungan hidup adalah model pembelajaran Problem Based Learning (PBL), Contextual Teaching Learning $(C T L)$, dan Inquiry. Pemilihan model pembelajaran diperlukan adanya kecocokan terhadap situasi dalam mengembangkan SSP, maka pemilihan model yang digunakan untuk menyiapkan siswa berperilaku ramah lingkungan adalah PBL. Menurut Arends (2008) ProblemBased Learning bertujuan untuk melatih peran dalam masyarakat dengan menyelesaikan permasalahan yang dihadapi, melatih berpikir lebih dalam dan bermakna menyangkut materi yang dipelajari, membangun pengetahuan dasar, membangun keterampilan berpikir, memecahkan masalah dan pengaturan diri. Model pembelajaran $P B L$ mengahadapkan siswa pada permasalahan sebagai dasar pembelajaran sehingga siswa mampu mengembangkan pengetahuan melalui pembelajaran bermakna pada materi lingkungan dan menerapkannya dalam kehidupann sehari-hari untuk berperilaku ramah lingkungan.

Berdasarkan latar belakang masalah dapat dirumuskan masalah "Bagaimana karakteristik, kelayakan dan keefektifan perangkat Subject Specific Pedagogy berbasis Problem-Based Learning yang dikembangkan untuk penguatan sikap peduli lingkungan siswa kelas VII SMP Negeri 2 Karanganganyar tahun pelajaran 2015/2016?"

Penelitian ini bertujuan untuk mengetahui karakteristik, kelayakan dan keefektifan perangkat Subject Specific Pedagogy berbasis Problem-Based Learning yang dikembangkan untuk penguatan sikap peduli lingkungan siswa kelas VII SMP Negeri 2 Karanganganyar tahun pelajaran 2015/2016

Hasil penelitian diharapkan dapat menjadi alat bantu perangkat pembelajaran guru yang digunakan untuk membelajarkan materi lingkungan pada mata pelajaran IPA sehingga siswa memiliki kesiapan peduli lingkungan.

\section{METODE PENELITIAN}

Penelitian merupakan penelitian pengembangan (Reseacrh \& Development) mengadaptasi model pengembangan $4 D$ yang termodifikasi menjadi $3 D$ dari Thiagarajan, et al (1975) yaitu terdiri dari pendefinisian (define), perancangan (design), pengembangan (develop). Tahapan secara rinci adalah sebagai berikut:

Tahap Pendefinisian (Define) dilakukan untuk menetapkan syarat-syarat yang dibutuhkan serta mengumpulakan informasi berkaitan dengan produk yang akan dikembangkan sesuai kebutuhan. Pertama, analisis ujung depan yaitu analisis silabus, analisis RPP, modul, LKS dan evaluasi serta identifikasi sekolah. yang menjadi tempat penelitian. Kedua, analisis peserta didik untuk mengetahui gambaran karakteristik siswa terkait dengan sikap peduli lingkungan melalui angket $N E P$ dan model pembelajaran yang akan digunakan. Ketiga, merumuskan tujuan untuk mengetahui tujuan yang akan dicapai dalam pembelajaran.

Tahap Perancangan (Design) untuk merancang perangkat pembelajaran dan instrumen sebagai alat uji kelayakan produk yang diberikan oleh validator. Pada tahap ini peneliti merancang perangkat SSP yang terdiri atas Silabus, RPP, Modul, LKS, dan alat Evaluasi. Perangkat SSP yang dihasilkan pada tahap ini disebut sebagai draf I yang selanjutnya akan divalidasi pada tahap pengembangan.

Tahap Pengembangan (Develope) yaitu untuk menghasilkan produk pengembangan. Tahapan dalam pengembangan SSP pertama pemilihan model pengembangan yang digunakan pada penelitian ini, yaitu menggunakan model pengembangan 3D yang dimodifikasi dari model 4D (four-D. Kedua, validasi perangkat untuk menilai kelayakan produk dari pengembangan. Data hasil validasi pengembangan SSP meliputi kelayakan instrumen silabus, RPP, modul, LKS dan alat evaluasi. Kegiatan menilai kelayakan atau validasi dilakukan oleh seorang dosen yang ahli dalam bidangnya yaitu ahli konstruk, ahli substansi, desain dan bahasa. Ketiga, Revisi I perangkat SSPmerupakan revisi produk awal berdasarkan hasil penilaian dan masukan yang diberikan oleh validator. Hasil validasi dari dosen digunakan untuk memperbaiki desain produk SSP sesuai hasil kelayakan dari para ahli sehingga layak diterapkan di lapangan. Hasil validasi yang disusun menghasilkan draft II, kemudian akan digunakan untuk uji coba terbatas. Keempat, uji coba terbatas digunakan untuk merevisi perangkat pembelajaran draft II dan dihasilkan perangkat pembelajaran berupa draft III. Uji coba terbatas yang dilakukan bertujuan untuk mendapatkan tanggapan, masukan, saran dan penilaian dari siswa dan guru terhadap draf II produk SSP. Perangkat SSP yang diuji cobakan adalah perangkat pembelajaran modul dan LKS. Uji coba terbatas dilakukan oleh kelompok kecil yaitu 5 siswa dan 1 guru mata pelajaran IPA. Kelima, revisi II produk merupakan hasil masukan dari siswa dan guru pada uji coba terbatas. Masukan tersebut digunakan untuk merevisi perangkat sebelum diujicobakan dalam skala yang lebih besar sehingga disebut hasil revisi II perangkat. Hasil revisi II perangkat menghasilkan draft III untuk digunakan uji coba lebih lanjut dengan siswa sesungguhnya. Keenam, uji coba subjek penelitian merupakan uji coba sesungguhnya dengan menerapkan produk SSP yang dilaksanakan di kelas VII A dan VII B berjumlah 63 siswa. Siswa dengan jumlah 63 tersebut melakukan proses pembelajaran IPA pada materi Pencemaran Lingkungan menggunakan produk SSP berbasis $P B L$ yang telah dikembangkan. Uji coba lapangan menghasilkan data berupa respon siswa terhadap modul dan lks, hasil belajar siswa meliput ranah kognitif berupa soal pretest dan postest, ranah afektif, dan ranah psikomotorik, serta pengukuran sikap peduli lingkungan dari hasil angket NEP. Uji coba subjek penelitian digunakan untuk mengukur keefektifan produk SSP berbasis $P B L$ yang telah dikembangkan.

Analisis data yan digunakan untuk menguji efektivitas SSP berbasis $P B L$ untuk penguatan sikap peduli lingkungan dengan teknik analisis sampel paired t-test SPSS 21 yang didahului dengan uji prasyarat yaitu uji normalitas dan ui homogenitas.

\section{HASIL DAN PEMBAHASAN}


Pengembangan SSP berbasis PBL yang menghasilkan perangkat pembelajaran untuk penguatan sikap peduli lingkungan. Berdasarkan observasi SMP Negeri 2 Karanganyar merupakan sekolah berbasis adiwiyata yang menanamkan pendidikan lingkungan hidup ke dalam materi pelajaran, sehingga terbentuk perilaku ramah lingkungan dalam keseharian. Implentasi sekolah adiwiyata dengan pemberian Pendidikan Lingkungan Hidup (PLH) belum sepenuhya direalisasikan dengan baik. Sekolah belum memberikan PLH yang diintegrasikan pada setiap mata pelajaran. Beberapa siswa kurang peduli dengan lingkungan sekitar sekolah.

Berdasarkan kondisi tersebut, perlu adanya pengembangan $S S P$ berbasis $P B L$ yang bertujuan untuk mengintegrasikan pendidikan lingkungan hidup melalui mata pelajaran IPA pada materi pencemaran lingkungan siswa meliputi silabus, RPP, LKS, modul serta alat evaluasi pada materi pencemaran lingkungan. Perangkat yang digunakan guru menunjukkan bahwa perangkat masih bersifat umum. Pada analisis silabus tidak dilakukan karena silabus kurikulum 2013 sudah jelas kevalidanya dan digunakan oleh semua sekolah SMP yang menggunakan kurikulum 2013. Analisis RPP pada perangkat pembelajaran guru terdapat beberapa indikator yang belum memuat materi spesifik mengenai pencemaran lingkungan. Keterlaksanaan sintaks pada RPP yang dibuat guru juga belum jelas perbedaannya antara kegiatan guru maupun kegiatan siswa. Modul yang digunakan sebagai perangkat pembelajaran pada guru maupun siswa, setelah dianalisis ternyata banyak materi yang belum memuat materi spesifik mengenai pencemaran lingkungan, kurang terintegrasinya indikator dalam $N E P$ serta pembelajaran $P B L$. Selain itu tampilan modul juga kurang menarik, sehingga siswa kurang antusias menggunakannya. Analisis LKS pada perangkat guru juga belum memuat semua indikator dalam NEP, dan tampilan LKS yang kurang menarik. Pada analisis perangkat evaluasi juga tidak mencakup semua indikator yang menjadi tujuan pembelajaran. Berdasarkan analisis yang dilakukan, maka peneliti mengembangkan perangkat SSP yang memuat materi spesifik yang mencakup indikator pada dimensi $N E P$ dan terintegrasinya pembelajaran $P B L$. Dimensi ekologi yang terdapat dalam NEP meliputi anti-anthripocentrism (AA), antiexemptionalism (AE), limit to grow ( $\mathrm{LtG})$, balance of nature $(\mathrm{BoN})$, dan eco-crisis (EC).

Sikap peduli lingkungan siswa masih kurang, dalam artian siswa belum memiliki kesiapan berperilaku ramah lingkungan. Data diambil berdasarkan angket NEP yang menujukkan hasil rata-rata angket 47,79 yang termasuk dalam kategori cukup peduli lingkungan. Hasil asnalisis tersebut belum menunjukkan kesiapan siswa dalam berperilaku ramah lingkungan, sehingga penguatan sikap peduli lingjkungan perlu ditingkatkan.

\section{Karakteristik SSP Berbasis $P B L$ Pada Materi Pecemaran Lingkungan}

Karakteristik pengembangan SSP berbasis $P B L$ adalah pengembangan perangkat $S S P$ yang terintegrasi dengan Problem Based Learning (PBL) dan 5 dimensi NEP. Perangkat SSP tersebut menghasilkan produk berupa silabus, RPP, modul, LKS serta soal evaluasi. Silabus dan RPP memuat 5 dimensi $N E P$ dalam setiap indikatornya. Selain itu dalam penyusunan perangkat RPP tahapannya memuat langkah model $P B L$ dan setiap kegiatan disesuaikan dengan indikator yang memuat dimensi $N E P$, begitu pula dengan modul, LKS, dan soal evaluasi. Soal evaluasi berjumlah 20 soal yang disesuaian dengan indikator yang sudah ditentukan.

Penyususnan perangkat SSP didasarkan pada tahapan dalam PBL. Integrasi PBL dalam perangkat mempunyai beberapa tahapan yaitu meeting the problem; problem analysis and learning issue; discovery and reporting; solution, presentation and reflection; dan overview, integration and evaluation.

Tahap pertama adalah meeting the problem (penemuan masalah) yang disajikan dalam bentuk artikel. Penemuan masalah didasarkan pada pengamatan artikel mengenai fenomena pencemaran, sehigga merangsang siswa untuk bertanya dan berpikir realistik berdasarkan fakta yang teridentifikasi (Tan, 2003). Kegiatan menemuan masalah akan menghasilkan rumusan masalah sebagai bahan pembelajaran berdasarkan tujuan pembelajaran.

Tahap kedua adalah Problem analysis and learning issues, ditunjukan dengan kegitan siswa menganalisis masalah berdasarkan artikel sehingga dapat menentukan topik permasalahan dari artikel dan permasalahan serupa di lingkungan sekitar. Informasi yang didapat dapat menentukan jawaban sementara (hipotesis) melalui rumusan masalah yang telah dibuat.

Tahap ketiga discovery and reporting ditunjukan dengan kegiatan siswa mencari dan menemukan cara untuk menyelsaian masalah melalui berbaga sumber nformasi dan melapokan informasi yang ditemuan dalam kelompok. Informasi yang didapatkan kemudian dilaporkan dalam bentuk tulisan dengan pengisian LKS.

Tahap keempat adalah solution, presentation and reflection ditunjukan dengan penulisan hasil diskusi berdasarkan penemuan solusi permasalahan. Siswa membandingkan hipotesis yang dirumuskan dengan studi literatur kemudian mempresentasikan hasilnya. Siswa juga membuat kesimpulan berdasarkan permasalahan yang dihasilkan.

Tahap kelima overview, integration and evaluation ditunjukan dengan menemuan konsep pembelajaran serta pengetahuan baru yang didapatkan selama pembelajaran, kesimpulan pembelajaran dan penugasan sebagai bentuk evaluasi siswa.

Model PBL yang terintegrasi dalam pembelajaran memberikan kesempatan siswa untuk aktif dalam menyelesaikan permasalahan yang dihadapi (Arends, 2008). Permasalahan disajikan berdasarkan masalah yang sering ditemukan dalam kehidupan sehari- hari, sehingga siswa mampu melakukan investigasi untuk mecari solusinya. Rangkaian aktivitas pembelajaran PBL memotivasi siswa untuk berpikir kritis serta mampu merangsang siswa menggunakan ketrampilan berpikirnya untuk memecahkan masalah. Husna, et al (2013) menyebutkan bahwa model pembelajaran PBL dapat menguatkan sikap peduli lingkungan, hal ini menegasakan 
bahwa tahapan dalam pembelajaran dapat melatih pembentukan sikap peduli lingkungan serta menerapkan pengetahuan dan keterampilanya dalam kehidupan seharihari.

Karakteristik SSP selanjutnya adalah adanya 5 dimensi NEP. Dimensi ini dijabarkan dalam materi pembelajaran bertujuan untuk penguatan sikap peduli lingkungan dengan angket NEP sebagai pengukuran (Dunlap, 2000). Integrasi 5 dimensi NEP dalam pengembangan SSP meliputi dimensi anti-anthripocentrism, anti-exemptionalism, limit to grow, balance of nature, dan eco-crisis. Materi disusun berdasarkan dimensi NEP sebagai indikator untuk mengukur sikap peduli lingkungan.

Dimensi anti-anthropocentrism komponen NEP ini pemahaman mengenai ego terhadap sumber daya dan lingkungan. Pandangan seseorang tidak mengedepankan ego ditunjukkan dengan peduli terhadap lingkungan, karena semua makhluk hidup mempunyai hak yang sama untuk memanfaatkan sumber daya alam yang ada. Dimensi ini dimasukkan ke dalam materi sumber pencemarn, pencegahan penanggulangan, aktivitas manusia yang menyebabakan pencemaran.

Dimensi anti-exemptionalism merupakan dimensi yang menunjukan pemahaman tentang tanggung jawab terhadap alam dan sumber daya yang tersedia. Manusia dengan kecerdasan yang dimiliki tetap harus tunduk dengan alam, sehingga mampu belajar mengolah serta mengendalikan sumber daya alam dan lingkungan. Terciptanya teknologi yang dibuat manusia tidak selalu dapat mengatasi permasalahan lingkungan, hal ini tergantung dengan tanggung jawab individu terhadap alam. Penjabaran dimensi di dalam materi adalah dampak pencemaran terhadap lingkungan, dampak teknologi yang diciptakan manusia terhadap lingkungan.

Dimensi Limit to growth komponen yang menunjukkan keterbatasan bumi dalam mendukung kehidupan manusia dan eksploitasi yang dilakukan manusia. Dimensi dijabarkan dalam materi sumber pencemaran, upaya penanggulangan serta dampak eksploitasi.

Dimensi balance of nature, mengenai keseimbangan alam yang mudah rusak yang terkadang adalah akibat ulah manusia sendiri. Penjabaran dimensi dimasukakan dalam materi mengenai penjelasan pencemaran, sumber pencemaran, dan aktivitas manusia.

Dimensi eco-crisis mengenai kerusakan alam dan krisis ekologi. Kerusakan alam terjadi akibat ulah manusia yang tidak berperilaku ramah lingkungan. Penjabaran dimensi dalam materi yaitu dampak teknologi, dampak pencemaran terhadap perubahan lingkungan dan aktivitas manusia yang menyebabkan pencemaran. Pembelajaran diharapkan mampu mendorong siswa untuk berperilaku ramah lingkungan sehingga mengurangi kerusakan alam.

\section{Kelayakan SSP Berbasis PBL Pada Materi Pencemaran Lingkungan}

Hasil uji kelayakan pada perangkat SSP dihasilkan presentase diatas minimal. Uji validitas dilakukan pada 4 aspek meliputi aspek konstruk, aspek substansi, aspek bahasa dan aspek desain. Hasil uji validasi konstruk pada perangkat Rencana Pelaksanaan Pembelajaran (RPP) mendapatkan presentase rata-rata sebesar $85,71 \%$ dari validator dosen sebesar $86,86 \%$ dan validator guru sebesar $86,86 \%$. Validasi konstruk perangkat Modul mendapatkan presentase rata-rata sebesar $85,75 \%$ dari validator dosen sebesar $85,50 \%$ dan validator guru sebesar $86 \%$. Validasi konstruk perangkat LKS mendapatkan presentase rata-rata sebesar $84,29 \%$ dari validator dosen dan validator guru sebesar $84,29 \%$. Validasi konstruk perangkat soal evaluasi mendapatkan presentase rata-rata sebesar $87,33 \%$ dari validator dosen sebesar $89,33 \%$ dan validator guru sebesar $85,33 \%$. Hasil validasi konstruk SSP menunjukkan dalam kategori sangat layak untuk kesemua perangkat, karena hasil validasi berada dalam rentang $83 \%$ hingga $100 \%$.

Hasil uji validasi aspek substansi perangkat modul mendapatkan presentase rata-rata sebesar $84,17 \%$. Hasil validasi substansi termasuk dalam kategori sangat layak, karena hasil validasi berada dalam rentang $83 \%$ hingga $100 \%$.

Hasil uji validasi aspek bahasa perangkat mendapatkan presentase rata-rata sebesar $92 \%$. Hasil validasi bahasa termasuk dalam kategori sangat layak, karena hasil validasi berada dalam rentang $83 \%$ hingga $100 \%$.

Hasil uji validasi aspek desain perangkat mendapatkan presentase rata-rata sebesar $89,09 \%$. Hasil validasi desain termasuk dalam kategori sangat layak, karena hasil validasi berada dalam rentang $83 \%$ hingga $100 \%$.

Hasil uji coba terbatas pada modul dan LKS dilakukan 5 responden siswa dan 1 responden guru. Hasil uji coba terbatas terhadap perangkat SSP berupa modul mendapatkan presentase rata-rata sebesar $86,80 \%$ dari responden siswa sebesar $88,60 \%$ dan guru sebesar $85 \%$. Hasil uji coba terbatas terhadap perangkat SSP berupa LKS mendapatkan presentase rata-rata sebesar 85,33\% dari responden siswa sebesar $85,90 \%$ dan guru sebesar $84,76 \%$. Hasil uji coba terbatas mendapatkan kategori sangat layak untuk digunakan uji coba subjek penelitian. SSP hasil uji coba subjek penelitian dinyatakan layak apabila hasil uji coba terbatas mendapatkan presentase minimal baik.

Hasil uji coba subjek penelitian terhadap perangkat SSP berupa modul mendapatkan presentase rata-rata sebesar $88,32 \%$ dari responden siswa sebesar $87,63 \%$ dan responden guru sebesar $89 \%$. Hasil uji coba subjek penelitian terhadap perangkat SSP berupa LKS mendapatkan presentase rata-rata sebesar 93,3\% dari responden siswa sebesar $88,27 \%$ dan guru sebesar $98 \%$. Hasil uji coba subjek penelitian mendapatkan kategori sangat layak untuk digunakan uji coba subjek penelitian karena dalam rentang $83 \%$ hingga $100 \%$. SSP hasil uji coba subjek penelitian dinyatakan layak untuk didiseminasikan apabila mendapatkan presentase minimal baik.

Secara umum produk SSP berbasis $P B L$ berada dalam kategori layak digunakan dalam penelitian sebagai perangkat pembelajaran di SMP N 2 Karanganyar. Saran perbaikan serta kritik uji validasi, uji coba terbatas maupun uji coba subjek penelitian digunakan sebagai bahan revisi produk sebelum menjadi produk akhir.

\section{Keefektifan SSP Berbasis PBL Pada Materi Pencemaran Lingkungan}


Kefektifan subject spescific pedagogy berbasis $P B L$ dapat diketahui dari hasil angket $N E P$ yang menunjukkan sikap peduli lingkungan siswa sebelum maupun sesudah penerapan $S S P$ berbasis $P B L$ pada materi pencemaran lingkungan. Berdasarkan Tabel 4.18. dapat diketahui bahwa rata-rata sikap peduli lingkungan siswa sebelum pembelajaran dan setelah penerapan perangkat pembelajaran $S S P$ berbasis $P B L$ mengalami peningkatan, sehingga dapat dikatakan SSP berbasis $P B L$ yang diterapkan dalam pembelajaran di kelas dapat membiasakan sikap peduli lingkungan siswa SMP N 2 Karanganyar.

Nilai angket NEP kemudian juga dihitung untuk mengetahui keefektifan SSP Berbasis $P B L$ dengan melihat hasil uji Paired sampel t-test yang disajikan dalam Tabel 4.21. Berdasarkan Tabel menunjukkan signifikansi lebih kecil dari $a$ ( sig. < 0,05) sehingga dapat dikatakan bahwa ada perbedaan yang signifikan hasil skor NEP awal dan NEP akhir. Pengembangan perangkat subject spescific pedagogy berbasis $P B L$ memiliki keefektifan untuk memberikan penguatan sikap peduli lingkungan siswa pada materi pencemaran lingkungan.

Kesimpulan dapat diambil bahwa perangkat subject spescific pedagogy berbasis $P B L$ yang diterapkan dalam pembelajaran dapat meningkatkan sikap peduli lingkungan siswa, sehingga terbentuk penguatan dan kesiapan untuk berperilaku. Ajzen (1991) menyebutkan bahwa kemauan seseorang untuk merubah sebagian perilakunya akan menentukan kebiasaan seseorang dalam berperilaku, sehingga sikap peduli lingkungan dapat dibentuk adanya kemauan yang ada dalam diri seseorang. Ahmad dalam Setyowati (2013) juga menyebutkan bahwa melalui pendidikan, seseorang dapat meningkatkan wawasan mengenai ekologi sehingga mampu menggerakkan perilaku ramah lingkungan, hal ini juga didukung oleh Irham dan Wiyani (2013) bahwa pembelajaran yang spesifik mengenai lingkungan akan memberikan kebiasaan berperilaku, dalam hal ini kebiasaan untuk bersikap peduli ligkungan.

Keefektifan subject spescific pedagogy berbasis $P B L$ juga dapat dilihat dari hasil belajar kognitif berupa pretest dan posttest. Data nilai pretest dan posttest yang diujikan telah memenuhi syarat homogen dan normal, selanjutnya dianalisis dengan uji paired sampel t-test. Berdasarkan Tabel 4.14. hasil belajar kognitif mengalami peningkatan nilai rata-rata setelah penerapan perangkat subject spescific pedagogy berbasis $P B L$ yang dilakukan dalam kegiatan pembelajaran. Hasil uji paired sampel t-test menunjukkan bahwa nilai signifikansi lebih kecil dari $a$ (sig. < 0,05), sehingga dapat dikatakan ada perbedaan hasil nilai kognitif pretest dengan hasil nilai posttest. Kesimpulan yang didapatkan perangkat subject spescific pedagogy berbasis $P B L$ mengalami peningkatan sehingga membuktikan bahwa perangkat SSP mampu meningkatkan hasil belajar siswa walaupun tidak signifikan. Berdasarkan pernyataan tersebut, hal ini karena peduli lingkungan merupakan materi pendidikan yang bersifat developmental, sehingga dibutuhkan waktu proses yang cukup panjang dan penguatan antara kegiatan belajar satu dengan yang lainnya dan kegiatan kurikuler. (Kemendiknas, 2010 dalam Khanafiyah, 2013).

Implikasi dari pengembangan perangkat $S S P$ berbasis $P B L$ yang terintegrasi dengan tahapan $P B L$ dan dimensi ekologi memungkinkan siswa untuk berinteraksi dengan lingkungan dan diharapkan dapat meningkatkan sikap peduli lingkungan siswa sehingga terbentuk penguatan akan sikap peduli lingkungan. sesuai dengan penelitian Husna et al (2013) bahwa keterlibatan siswa belajar dengan menggunakan model $P B L$ dapat meningkatkan sikap peduli lingkungan siswa. Pembelajaran model $P B L$ memberikan manfaat kepada siswa dalam memecahkan masalah. Arends (2008) menyebutkan bahwa model PBL akan medorong siswa berpikir aktif dalam penyelesaian masalah, membangun pengetahuan dasar, memecahkan masalah dan pengaturan diri, sehingga materi lingkungan dapat dipahami dan diterapakan dalam kehidupan seharihari dalam bentuk sikap peduli lingkungan, serta memberikan penguatan sikap peduli lingkungan.

\section{KESIMPULAN}

Kesimpulan yang diperoleh dari penelitian pengembangan $S S P$ berbasis $P B L$ adalah sebagai berikut:

1. Pengembangan subject specific pedagogy berbasis problem based learning $(P B L)$ materi pencemaran lingkungan untuk penguatan sikap peduli lingkungan lingkungan dilakukan dengan menggunakan model pengembangan 4D yang termodifikasi menjadi 3D (define, design, dan develop) dari thiagarajan. Tahapan penelitian pengembangan melaui analisis ujung depan, validasi, revisi perangkat, uji coba terbatas, dan uji coba subjek penelitian atau uji lapangan, sehingga mengahasilkan produk akhir berupa $S S P$ berbasis $P B L$ yang layak digunkan

2. Produk pengembangan subject specific pedagogy berbasis problem based learning $(P B L)$ materi pencemaran lingkungan berupa silabus, RPP, LKS, modul dan evaluasi.

3. Karakteristik subject specific pedagogy berbasis problem based learning $(P B L)$ materi pencemaran lingkungan merupakan inegrasi dari model $P B L$ dan integrasi 5 dimensi NEP

4. Kelayakan subject specific pedagogy berbasis problem based learning (PBL) materi pencemaran lingkungan setelah dilakukan uji validasi berada dalam katagori baik dan layak digunakan.

5. Efektifitas subject specific pedagogy berbasis problem based learning (PBL) materi pencemaran lingkungan dinyatakan efektif menguatkan sikap peduli lingkungan, meningkatkan pengetahuan, sikap, dan ketrampilan siswa

Hasil penelitian ini secara teoritis dapat dijadikan sebagai referensi bagi penelitian pengembangan dalam rangka mengembangkan perangkat pembelajaran yang 
dapat membantu siswa menguatkan sikap peduli lingkungan. Secara praktis dapat dijadikan sebagai alternatif dalam membantu siswa memahami materi pencemaran lingkungan.

\section{UCAPAN TERIMAKASIH}

Peneliti menyampaikan terima kasih pada seluruh pihak yang membantu terselesaikannya penelitian ini hingga tahap penyusunan laporan.

\section{DAFTAR PUSTAKA}

Ajzen, Icek. (1991). The Theory of Planned Behavior. Organization Behavior and Human Decision Processes 50, 179-211.

Ajzen, Icek. (2001). The Theory of Planned Behavior. Journal of Organization Behavior and Human Decision Processes, 179-211

Amir, M. T. (2013). Inovasi pndidikan Melalui Problem Based Learning: Bagaimana Pendidik Memberdayakan Pemelajar Di Era Pengetahuan. Jakarta: Kencana Prenada Media Group.

Arends, R. (2008). Learning to Teach. Yogyakarta: Pustaka Pelajar

Astuti, R. P., \& Junaedi, I. (2013). Peningkatan Aktivitas Dan Hasil Belajar Melalui Pbl Pada Siswa . Lembaran Ilmu Kependidikan, Volume 42; NO. 2; ISSN 02160847.

Azwar, S. (2002). Sikap Manusia Teori dan Pengukuranya. Yogyakarta: Pustaka Pelajar

Barlia, Lili. (2006). Mengajar dengan Pendekatan Lingkungan Alam Sekitar (PLAS) untuk Guru dan Calon Guru SD). Jakarta: Depdiknas Dirjen Dikti

BNPB. (2011). Materi presentasi BNPB (Badan Nasional Penanggulangan Bencana) yang disampaikan dalam Pelatihan Dasar Penanggulangan Bencana. Jakarta: Kementrian Lingkungan Hidup. On Line www.Menlh.go.id. di akses 11 Januari 2016.

BSNP. (2006). Panduan Penyusunan Kurikulum Tingkat Satuan Pendidikan Jenjang Pendidikan Dasar Dan Menengah. BadanStandar Nasional.

Departemen Pendidikan Nasional. (2008). Panduan Umum Pengembangan Silabus. Direktorat Pengembangan Sekolah Menengah Atas.

Dunlap, Riley E., et. all. (2000). Measuring Endorsement of the New Ecological Paradigm: A Revised NEP Scale. Journal of Social Issues, Vol. 56, No. 3

Dursun, Carner., et all. (2015). The Effect of Problem Based Learning Method on the Environment Awarness of 7th Graders. International Journal of Education and Research. Vol.3. No.5. ISSN: 24115681

Farhati, F.(1995). Sikap Ekosentrik dan Antroposentrik Terhadap Lingkungan. Laporan Studi Kasus. Yogyakarta: Fakultas Psikologi UGM

Galus, Ben Senang. (2010). Pendidikan Lingkungan Hidup: Untuk Sebuah Keberlanjutan Hidup Bersama. Online. http://www.pendidikandiy.go.id/dinas v4/?view=v artikel\& $\mathrm{id}=4$, diakses tanggal 11 Januari 2016
Hamdani. (2011). Strategi Belajar Mengajar. Bandung: CV. Pustaka Mulia

Hamid, Ahmad Abu. (2009). Penyusunan RPP (Rencana Pelaksanaan Pembelajaran Ilmu Pengetahuan Alam (IPA). Yogyakarta: Universitas Negeri Yogyakarta

Harum M. Huasein. (1993). Lingkungan Hidup: Masalah Pengelolaan dan Penegakan Hukumnya. Jakarta: PT. Bumi Aksara

Husna, Syarifah. (2013). Penerapan Model Problem Based Learning Pada Konsep Perusakan dan Pencemaran Lingkungan Untuk Meningkatkan Sikap Peduli Lingkungan Siswa SMA Negeri 1 Sabang. Jurnal EduBio Tropika. Vol 1 Nomor 2, hlm. 61-120

Ibrahim, M., dan Nur, M. (2005). Pengajaran Berbasis Masalah. Surabaya: University Pres

Irham, M \& Novan Ardi Wiyani. (2013). Psikologi Pendidikan Teori dan Aplikasi dalam Proses Pembelajaran. Yogjakarta: Ar-Ruzz Media, hal. 116

Jutmini, Sri. (2007). Panduan Penyusunan Silabus dan Rancangan Pelaksanaan Pembelajaran. Surakarta: Universitas Sebelas Maret.

Jolly, J., \& Jacob, C. (2012). A study of problem based learning approach for undergraduate students.Asian Social Science, 8(15), p157.

Kementrian Lingkungan Hidup Republik Indonesia. (2013). Status Lingkungan Hidup Indonesia 2012. Jakarta : Kementrian Lingkungan Hidup Republik Indonesia

Kollmuss, A., dan Agyeman, J.A., (2002). Mind the Gap: Why Do People Act Environmentally and What Are The Barriers to Pro-Environmental Behavior? Environmental Education Research, 8(3):239-260.

Keraf, S. (2005). Etika Lingkungan. Jakarta: Kompas

Majid, Abdul. (2007). Perencanaan Pembelajaran. Bandung: PT Remaja Rosdakarya

Masrusri, dkk. (2002). Pendidikan Kependudukan dan Lingkngan Hidup. Yogyakarta: UNY Press

Mustakin, Bagus. (201)1. Pendidikan Karakter Membangun Delapan Karakter Emas Menuju Indonesia Bermartabat. Yogyakarta: Samudra Biru.

Narwanti, Sri. (2011). Pendidikan Karakter Pengintegrasian 18 Nilai Peembentuk Karakter dalam Mata Pelajaran. Yogyakarta: Familia

Ngalawiyah, Lutfi. (2014).Studi Deskriptif Implementasi Nilai Peduli Lingkungan Menuju Sekolah Adiwiyata Di SDN Tukangan Yogyakarta. UNY:FIP.

Nurani, Novian P, et all . (2014). Pengembangan Modul Pendidikan Lingkungan Hidup (Plh) Berbasis Karakter Untuk Menumbuhkan Wawasan Dan Karakter Peduli Lingkungan. Unnes Journal of Biology Education 3 (1) ISSN 2252-6579

Panen, P. (2001). Belajar Dan Pembelajaran 1. Jakarta: Pusat Penerbitan

Palmer and Neal. (1994). The Handbook of Environmental Education. London: Routledge.

Prasetyo, Z. K. (2011). Pengembangan Subject Pedagogy (SSP) Berbasis Lima Domain Sains untuk Menanamkan Karakter Siswa SMP. Prosiding, 367368

Primarinda, Ikha. et all. (2014). Pengembangan Modul Berorientasi Problem Based Learning (PBL) Pada Materi Pencemaran Untuk Memberdayakan 
Kemampuan Berpikir Kritis dan Sikap Peduli Lingkungan Siswa SMA Negero 1 Karanganyar. Universitas Sebelas Maret.

Priyanto, Yuli,. dkk. (2013). Pendidikan Berperspektif Lingkungan Menuju Pembangunan Berkelanjutan: Environmental Perspective Education Towards Sustainable Development. Wacana-Vol. 16, No. 1. Program Studi Kajian Lingkungan dan Pembangunan, Program Pascasarjana Universitas Brawijaya

Priyatno, Duwi. (2010). Paham Analisa Statistik Data dengan SPSS. Plus Tata Cara dan Tips Menyusun Skripsi dalam Waktu Singkat. Yogyakarta: Mediakom.

Rahmawati, I ., \& Suwanda, I. M. (2015). Upaya Pembentukan Perilaku Peduli Lingkungan Siswa Melalui Sekolah Adiwiyata di SMP N 28 Surabaya. Kajian Moral dan Kewarganegaraan, 1, pp.71-88. Surabaya

Raka, Gede., dkk. (2011). Pendidikan Karakter di Sekolah, dari Gagasan ke Tindakan. Jakarta : PT. Elek Media Komputindo

Rusmono. (2012). Strategi Pembelajaran Dengan PBL Itu Perlu. Bogor: Ghalia Indonesia

Sanjaya, Wina. (2007). Kurikulum dan Pembelajarn Teori dan Praktik Pengembangan Kurikuum Tingkat Sauan Pendidikan. Jakarta: Kencana

Sanjaya, W. (2009). Strategi Pembelajaran Berorientasi Standar Proses Pendidikan. Jakarta: Kencana

Scoullos, Michael J. (2010). Education for Sustainable Development: The Concept and Its Connection to Tolerance and Democracy. New Delhi: SAGE.

Setyowati, Ratna., Parmin, \& Widiyanto, Arif. (2013). Pengembangan Modul IPA Berkarakter Peduli Lingkungan Tema Polusi Sebagai Bahan Ajar Siswa SMKN 11 Semarang. Unesa Selence Education Journal. Vol 2 (2).

Soemarwoto, O. (2001). Atur Diri Sendiri Paradigma Baru Pengelolaan Linkungan Hidup. Yogyakarta: Gajah Mada University Press

Sudjana, N., dan Rivai, A. (2007). Media Pengajaran. Bandung: Sinar Abaru Algasindo

Sudjana, N. (2009). Penilaian Hasil Proses Belajar Mengajar. Jakarta : Remaja Rosdakarya.

Sugiyono. (

2009). Metode Penelitian Pendidikan. Bandung: Alfabeta.

Suharsimi, A. (2010). Prosedur Penelitian Suatu Pendekatan Praktik. Jakarta: PT. Rineka Cipta

Sujarwo. (2011). Model-Model Pembelajaran Suatu Strategi Mengajar. Yogyakarta : Venus Gold Press

Sukmadinata, Nana. (2005). Metode Penelitian Pendidikan. Bandung: PT. Remaja Rosdakarya

Sumarmi. (2008). Sekolah Hijau Sebagai Alternatif Pendidikan Lingkungan Hidup Dengan Menggunakan Pendekatan Kontekstual. Jurnal Ilmu Pendidikan. Jilid 15 Nomor 1. Halaman 19-25.

Susilowati, et all. (2013).Pengembangan Subject Spesific Pedagogy untuk Pembelajaran IPA Terintegrasi Menggunakan Model Project Based Learning, Problem Based Learning, Guided Inquiry untuk meningkatkan Keterampilan Proses dan Keterampilan Berpikir Kritis (Critical Thinking)Siswa SMP. Universitas Negeri Yogyakarta.
Syah, M. (2010). Psikologi Pendidikan dengan Pendekatan Baru. Bandung: PT Remaja Rosdakarya

Tan, O. S. (2003). Prolem-Based Learnig Innovaton: Using Problem To Power Learnig In The 21st Century. Singapore: Cengage Learning

Tatat Hartati, dkk. (2009). Productive Pedagogy \& Subject Spesific Pedagogy. Bandung: Universitas Pendidikan Indonesia (UPI) Bandung

Trianto. (2012). Model Pembelajaran Terpadu. Jakarta: Bumi Aksara

Trianto. (2010). Model Pembelajaran Terpadu. Jakarta: Bumi Aksara

Widjayanti, E. (2008). Pelatihan penyususnan LKS Mata Pelajaran Kimia Berdasarkan KTSP Bagi Guru SMK. Yogyakarta: uny

Wijaya, C. (1988). Upaya Pembaharuan Dalam Pendidikan dan Pengajaran. Bandung: Remadja Karya.

Yulianti, Titik. (2014). Pengembangan Modul Berbasis Problem Based Learning Materi Pencemaran Lingkungan Untuk Membiasakan Sikap Peduli Lingkungan Siswa SMP Negeri 1 Bulu Sukoharjo. Skripsi Tidak Dipublikasikan. Universitas Sebelas Maret: FKIP. 